GRADUATE SCHOOL

OF INDUSTRIAL ADMINISTRATION

WILLIAM LARIMER MELLON, FOUNDER

REPRINT No. 584

\title{
What the Commission \\ Didn't Recommend
}

by

Allan H. Meltzer

1972

Carnegie-Mellon University

PITTSBURGH, PENNSYLVANIA 15213 


\title{
Graduate School of Industrial Administration
}

William Larimer Mollon, Founder

\section{Carnegie-Mellon University}

\author{
Pittaburgh, Pennsylvania 15218
}

\section{SOME CURRENT REPRINTS}

466. Market Structure, Elasticity of Demand, and Incentive to Invent, by Morton I. Kamien and Nancy L. Schwartz.

467. Maneuvering Llquid Assets in a Multl-National Company: Formulation and Deterministic Solution Procedures, by David P. Rutenberg.

468. Hospital Cost Function, by Judith and Lester Lave.

469. Dlfferent Approaches to Advertising Media Selections, by Dennis H. Gensch.

470. Bayeslan Analysis and Duopoly Theory, by Richard M. Cyert and Morrls H. DeGroot.

471. Improving the Capital Adequacy Formula, by Kalman J. Cohen.

472. Programming Bank Portfolios Under Uncertainty, by Kalman J. Cohen and Sten Thore.

473. The Supply of Labor and Manufacturing Wage Determination in the United States: An Empirical Examination, by Timothy W. McGuire and Leonard A. Rapping.

474. Estlmated Cost Function for Pennsylvanla Hospltals, by Judith and Lester Lave.

475. Laboratory Versus Lecture in Training Executives, by Lee Bolman.

476. The Kennedy-Johnson CEA, by Martin Bronfenbrenner.

478. Factor Market Imperfections, Increasing Marginal Returns, and Optimum Input Proportlons, by Norman C. Miller.

479. Size of Coaltion and Electoral Outcomes in the Fourth French Republic, by Howard Rosenthal.

481. The Viscissitudes of Marxlan Economics, by Martin Bronfenbrenner.

482. Union Induced Raclal Entry Barriers, by Leonard Rapplng.

483. A Note on the Detection of Interaction, by Richard Staellin.

484. L'inference des propriotes individuelles a partlr de donnees agregees: Problemes de collinearite, by Howard Rosenthal and Naomi E. Kles. (in French)

486. Cost-Benefit Analysis as a Statistical Hypothesis Test: An Example from Urban Transportation, by John O. Ledyard.

487. Factor-Augmenting Technical Advance in a Two-Sector Open Economy, by Norman C. Miller and Nancy Schwartz.

488. The E-Model of Chance-Constrained Programming, by Robert S. Kaplan, John V. Soden and Mark J. Eisner.

489. Validation of Simulation Results, by Richard L. Van Horn.

490. On the Objectlve Function for the Sequentlal P-Model of Chance-Constrained Programming, by Robert S. Kaplan and John V. Soden.

491. Multiperlod Declsion Models with Alternating Choice as a Solution to the Duopoly Problem, by R. M. Cyert and M. H. DeGroot.

492. Reducing the Rank of A-B, by Gerald $L$. Thompson and $R$. $L$. Weil.

493. The Stabllity of Post-Decision Dissonance: A Follow-Up Study of the Job Attitudes of Business School Graduates, by Edward L. Deci and Victor H. Vroom.

494. Intersection Cuts - A Now Class of Cutting Planes for Integer Programming, by Egon Balas.

495. Three Pricing Policies for a Multi-Product, Multi-National Company, by David P. Rutenberg.

496. A Unifled Approach to the Theory of Accounting and Information Systems, by Claude S. Colantoni, Rene P. Manes and Andres Whinston.

497. Applications of Mathematical Control Theory to Flnance: Modeling Simple Dynamic Cash Balance Problems, by Suresh P. Sethi and Gerald L. Thompson.

498. Sequential Models in Probabilistic Depreciatlon, by R. S. Kaplan and Yujl IjIrl.

499. A Benefit-Cost Analysis of Auto Safety Features, by L. B. Lave and W. E. Weber. 500. Medlcal Care and Its Delivery: An Economic Apprisal, by Judith R. Lave and Lester B.
Lave.

501. Radical Economics in America: A 1970 Survey, by Martin Bronfenbrenner. 503. An Intersection Cut from the Dual of the Unit Hypercube, by Egon Balas, V. J. Bowman,

505. On the Asymptotic Convergence Rate of Cost Dlfferences for Markovian Processes, by Thomas E. Morton.

506. Investment Diversification and Bond Maturity, by R. W. Roll.

507. Diminishing Returns from Taxation? The Case Re-Examined, by Martin Bronfenbrenner.

508. Design Commonality to Reduce Multi-Item Inventory: Optimal Depth of a Product Line, by Davld P. Rutenberg.

(Continued on inside back cover) 


\section{ALLAN H. MELTZER}

\section{What the Commission Didn't Recommend}

THE BASIC WORK OF THE COMMISSION ON FINANCIAL STRUCTURE was negotiation. The restrictions on competition in the banking laws and regulations create monopoly positions, two of which turned out to be most important for the members of the commission. Protracted negotiation was required because the commission had to discover the price that commercial bankers were willing to pay to the depository thrift institutions to get them to give up Regulation $Q$ and the $1 / 2$ percent difference in deposit rates maintained by regulation. The price was a share of the commercial banks' monopoly on the demand deposit business and their claim to "one-stop" banking.

If we step back from the negotiations and the calculation of the gains and losses to particular institutions, we recognize that the principal gains are to the public and only incidentally to one or another type of financial institutions. This is not an accidental by-product of the report; it is the principal thrust of the report. With little equivocation, the commission took the view that generally competition is a more efficient, more flexible, more effective regulator in the public interest than any agency or group of agencies, no matter how high-minded and dedicated their personnel. In an era of increasing regulation, at a time when economic freedom is often treated as worthless, this is a rare, correct and happy conclusion. I applaud the commission for reaching it.

Why did the commission reach its conclusion with so few dissents? My observation of the discussion suggests a simple answer. The commissioners compared the promise of regulators to their performance. The gulf between the regulators' promise that Regulation Q would serve as the "cutting edge of monetary policy" and the performance was so large that not even the main dissent from the AFL-CIO en-

ALLAN H. MELTZER is Maurice Falk Professor of Economics and acting dean of the Gradu. ate School of Industrial Administration, Carnegie-Mellon University. Publication of this paper is made possible by the support of the Center for Research in Government Policy and Business at the University of Rochester. 
dorses this particular regulation. Now, more than two years after the peak in economic activity, we are still experiencing the domestic and international consequences of the very large changes in assets induced by this pernicious regulation. The banks wanted to be done with Regulation $Q$ and the savings and loans were willing to go along if they were given enough in return.

The commission saw its charge, I believe, as the development of a financial structure that would be less prone to crises and disturbances than the present structure. The faults of the present structure, to a considerable extent, stem from two unstated premises of the banking acts of the 1930s. One premise, that the banking laws share with most other legislation in the early New Deal, is that competition generally produces harm. Whatever the problem, every New Deal regulator believed that if he had more power he would solve more problems. To a considerable extent this view is still with us. The commission members had considerable experience with the promises of regulators and had acquired some skepticism about their ability to deliver the results they promised. Equally important, the members had experienced Mr. James Saxon as comptroller and had learned that most of the dire consequences of competition-predicted by Saxon's adversaries-had not occurred because of competition but because of regulation.

The main departures from the view that competition works are the failure to remove the prohibition on interest payments on demand deposits, the failure to permit national banks or savings institutions to branch nationally, and the failure to remove all restrictions on portfolios. The commission stated well much of the case for paying interest on demand deposits. The commissioners were aware of empirical findings that demolish the case against competition, but the commercial bankers were unwilling to pay much for the privilege of paying interest directly rather than by giving services as they now do. The commission never seriously considered national branching, and it departed from its encouraging statements about competition by refusing to break the commercial banks' monopoly on business deposits.

Important as these departures from the commission's stated principles are, they are not my main points. The second premise of financial regulation on which I wish to comment is the structural view-the view that the main problems of the industry result from structural weaknesses. In the thirties, the structural view produced a lot of words about overbanking and discussion of the inherent weaknesses of the financial system. The problem was that the system had been unable to cope with the excessively deflationary policies of the Federal Reserve in 1920-21 and again in 1929-33. The restrictions on entry, branching, portfolio practices, regulation of interest rates, variation in reserve requirement ratios were accepted in the mistaken belief that these would prevent excessive expansion leading to structural weakness and collapse.

The main tendencies of the postwar years have been growth and inflation, not the contraction and deflation that were expected when the Banking Acts were written.

However, the commission refused to consider the role Federal Reserve policies played in causing the very unstable financial and economic conditions from 1966 to the present, just as their predecessors refused to consider the Fed's role in the de- 
pression. None of their proposed structural reforms can protect the financial system against the consequences of the excessively variable government policies of the past few years. If, as I believe, the evidence is overwhelming that mistaken government policies are the main cause of fluctuations in the economy, there is no set of structural reforms that can protect financial institutions of the type we know-institutions that lend for longer-term than they borrow and whose principal assets and liabilities are fixed in nominal value.

The weakest link in the financial system is the Federal Reserve System. The Commission on Financial Structure did nothing to reduce the arbitrary power of the Federal Reserve or to assure that in the future the Federal Reserve would behave responsibly. Since there is very little in the history of the Federal Reserve, or other central banks, to show that they learn much from past mistakes, I believe we can expect excessive monetary expansion to be followed periodically by excessive contraction. Certainly nothing in recent experience causes us to expect anything else.

Not only did the commission fail to recommend procedures for limiting variability of Federal Reserve policy, it required all banks to become members of the Federal Reserve System on the mistaken and incorrect grounds that membership strengthens monetary policy. Instead of eliminating reserve requirements for deposits the CFSR subjected everyone to the type of variability that has been a problem in the past.

In perhaps the most famous book on central banking ever written, Walter Bagehot set out the case for a lender of last resort. The basic argument of his Lombard Street is that the central bank is the lender of last resort to the entire financial system, that there can be only one such lender, and that the lender is the only agency capable of preventing a money panic or stopping a panic once it has started.

Every financial system requires an institution to serve as lender of last resort to the system. In the event of widespread financial failures, large deposit withdrawals, and a rising demand for currency, the lender of last resort issues base money, particularly currency, on demand. The failure of the Federal Reserve in the 1930s to function as lender of last resort added substantially to the depth and severity of the panic and the size of the losses to individuals and to society. Eventually, a large part of the financial system was destroyed and with it went a belief in the power of market forces to regulate.

The experience of the thirties produced two changes affecting the lender of last resort. First, the Federal Reserve System appears to have accepted responsibility for preventing widespread failures. Experience during the recessions of 1966 and 1970 shows that the Federal Reserve now holds a different view of the appropriate activities in time of crisis and its responsibility as lender of last resort to the financial system. Second, deposits at most commercial banks and savings institutions are now insured by FDIC and FSLIC. In any future panic, depositors are insured against losses.

However, no mechanism is established by law or agreement that assures that FDIC or FSLIC can promptly pay depositors during a panic. Both corporations 
hold government securities with a relatively short-term to maturity. Generally, their securities are readily marketable. In a large financial panic, however, they would have difficulty finding buyers other than the central bank. If the central bank refused to buy, delayed purchasing, or refused to purchase sufficient quantities, prompt payment of depositors' losses could not be made by the deposit insurance agencies.

However small one believes the probability that the Federal Reserve would repeat its errors of the 1930s, there is no reason to leave the decision to intervene to the judgment of the individuals who happen to be on the Board of Governors of the Federal Reserve System during some future crisis. A main reason for government insurance of deposits is to avoid the risk that the insurer would be unwilling or unable to pay depositors promptly.

Two changes are required to clarify the lender of last resort function:

(1) The conditions under which FDIC and FSLIC have the right to demand that the Federal Reserve purchase securities for base money should be made more precise.

(2) The responsibility of the Federal Reserve as lender of last resort to the financial system-not just to member banks, commercial banks, or some other subset of the system-should be established by law or binding agreement among the relevant groups.

Both changes would contribute to stability and efficiency.

The commission proposed a number of important changes-both broad and narrow. Many of these changes, if adopted, increase efficiency, freedom and the opportunity for financial institutions to protect their owners and their depositors from arbitrary and inappropriate actions and particularly the actions of the Federal Reserve System. In my judgment, the main missing element is attention to the main problem.

Let me turn now briefly to the problems of chartering, entry and supervision. The commission probably did not go far enough in separating examination, supervision and deposit insurance. George Benston's paper for the commission argued strongly, and I believe correctly, that examiners and their agencies impose their views on banks and thrift institutions. Without the consent of the examining agencies, branches are not granted, new charters are not issued, mergers are not approved. Examiners in many states reduce innovation and restrict competition by a lack of receptivity to new ideas and new approaches, which, if accepted, bring more and better services to consumers.

Benston's analysis of the data showed that most bank failures are the result of frauds and are not detected in advance by examiners. He concluded that there was considerable gap between the reasons used to justify bank examination and the results of examination. His study suggests that the principal effects of examination are anti-competitive and anti-innovative.

According to Benston, the correct reason for having examination is to protect the insurance fund. A problem arises because the cost of insurance does not vary with 
the amount of risk taken by an individual bank. Some bankers are encouraged to take on risks that they would forego if the insurance premium was based on the true probability of failure. If the present system of insurance is maintained, the in. surance agency has to examine banks to assess risk.

There is no reason for the FDIC or FSLIC to decide on branching and mergers and no reason to relate examination and bank expansion or branching. Also, no clear or demonstrated relation has ever been shown to exist between examination and monetary policy. Whatever the phrase "quality of credit" may mean, there ought to be evidence that the Federal Reserve uses data on the "quality of credit" to determine monetary policy if such data are as important as sometimes claimed. Otherwise, some of us will conclude that this is only one more case of arguments without evidence.

My view is that there is confusion between the consequences of individual bank failure and consequences of a wave of failures. It is the latter that concerns society and gives rise to the importance of assuring that the function of lender of last resort is filled, that the role of the lender is clear and that he will not again miss the call to action. In the concern for regulating, supervising, and restricting individual banks, the present system has failed to provide adequate safeguards against another wave of failures that would destroy the banking and financial systems.

The failure is, as I mentioned earlier, a consequence of the unclear relation between the insurance fund and the Federal Reserve or the Treasury. Until this relation is clarified, the risk remains.

To remedy this weakness, I believe the commission should have recognized two principles. First, there is no reason that individual banks cannot insure their deposits by buying insurance from a private company. Private insurance companies would be motivated to provide insurance at rates that cover the expected loss from the failure of a single bank. The anti-competitive, anti-innovative aspects of examination and supervision would be removed. Second, the risk of failure of the insurance fund requires government action because there is always the chance that large errors in monetary policy will destroy the banking system. To avoid the consequences of these errors, the government need not be in the insurance business. It must make sure that the insurance company pays its claims promptly. This is the task of the lender of last resort.

Our present system of insurance puts the government into a business where it need not be but fails to make certain that government will perform the functions that only a lender of last resort can perform. 
510. Effects of Mergers and Acquisitions on Business Firm Concentration, by Yujl IjIrl and Herbert A. Simon.

511. Congestion and Urban Location, by Lester B. Lave.

512. A Reconsideration of "Nlxonomics" and "Stagflation", by Martin Bronfenbrenner.

513. Overhead Allocation Via Mathematical Programming Models, by Robert Kaplan and Gerald Thompson.

514. Further Consideration of "An Open Expanding Economy Model", by Oskar Morgenstern and Gerald $L$ Thompson.

515. Japan's Galbraithian Economy, by Martin Bronfenbrenner.

516. A Duality Theorem and an Algorithm for (Mixed-) Integer Nonlinear Programming, by Egon Balas.

517. Undlscounted Markov Renewal Programming via Modlfled Success Approximations, by Thomas E. Morton.

518. A Finiteness Proof for Modifled Dantzig Cuts in Integer Programming, by V. J. Bowman and G. L. Nemhauser.

519. Duality in Dlscrete Programming, by Egon Balas.

520. Algorithm 405 Roots of Matrix Pencils: The Generalized Eigenvalue Problem [F2], by Alice M. Dell, Roman L. Well, and Gerald L. Thompson.

521. Autoregressive Approaches to Temporial Disaggregation, by K. Y. Cohen.

522. Product Design: Subassemblies for Multiple Markets, by David P. Rutenberg and Timothy L. Shaftel.

523. Stochastic Growth Models, by Robert S. Kaplan.

524. Analysis of Distributed Lag Models with Applications to Consumption Function Estimation, by Martin S. Gelsel and Arnold Zellner.

525. The Extent of Role Differentiation Among Hospitals by Judlth R. Lave and Lester B. Lave.

526. Measurements in Accounting, by Y. Ijiri, R. Mattessich, A. Rappaport, E. L. Summers, and A. L. Thomas.

527. Health and Air Pollution, by Lester B. Lave and Eugene P. Seskin.

528. Toward a Comprehenslve Framework for Bank Financial Planning, by Kalman J. Cohen and David P. Rutenberg.

530. The Effect of Discounts on the Computation of Optimal Media Plans by Robert S. Kaplan and Allan D. Shocker.

531. Optimal Management of a Research and Development Project, by R. E. Lucas.

533. The "Structure of Revolutions" In Economic Thought, by Martin Bronfenbrenner.

534. Market Measures from Salesmen: A Multidimensional Scaling Approach, by Ronald E. Turner.

535. An Analysis of the Demand for Emergency Ambulance Service In an Urban Area, by Carole A. Aldrich, John C. Hisserich, and Lester B. Lave.

536. Multivariate Analysis of Differences in Buyer Decision Time by Joseph W. Newman and Richard Staelin.

537. Some Effects of Trainers on Their T-Groups, by Lee Bolman.

538. Relatlonship Between Age and Risk Taking Among Managers, by Victor Vroom and Bernd Pahl.

539. Critlque of the APB Fundamentals Statement, by Yujl ljirl.

540. The Near-Myopic Nature of the Lagged Proportional Cost Inventory Problem with Lost Sales, by Thomas E. Morton.

541. A Model for Integrating Sampling Objectives In Auditing, by Yuji IJiri and Robert S. Kaplan.

542. Fundamental Querles in Aggregation Theory, by Yuji Ijiri.

543. Another Look at A.I.D. by Richard Staelin.

544. Testing for a Shift in the Slopes of a Multi-Variate Linear Time Series Model, by John U. Farley, Melvin J. Hinich, and Timothy W. McGulre.

545. Adaptive Decision Rules for Macroeconomic Planning, by Edward C. Prescott.

546. Efficlent Capital Markets and External Accounting, by Nicholas J. Gonedes.

547. Unemployment in the Great Depression: Is There a Full Explanation?, by Robert E. Lucas, Jr. and Leonard A. Rapping.

548. A Note on Zero-One Integer and Concave Programming, by Joseph V. Bowman and Fred Glover.

550. Investor Evaluation of Accounting Information by Robert S. Kaplan and Richard Roll.

551. Expectations and the Neutrality of Money by Robert E. Lucas.

552. Investment under Uncertainty by Robert E. Lucas and Edward Prescott.

553. The Roots of Matrix Pencils $(A y=\lambda B y)$ : Existence, Calculations and Relations to Game Theory by Gerald Thompson and Roman L. Weil.

554. A Partial Utility Approach to the Theory of the Firm by Azariadis Costas, Kalman J. Cohen, and Alfredo Porcar.

555. On Capital Overaccumulation in the Aggregative, Neoclassical Model of Economic Growth: A Complete Characterization by David Cass.

(Continued on back cover) 
The prevent series contalns articles written by the faculty of the Graduate School of induetulal Adninibtration. Publleatlons began in the 18s2-63 academic year and continue through to date. You may request coples and receive them from: Reprint Secretary, Gsih, Camegle-Mellon University, Pitteburgh, Penne 15213.

556. Dlstingulahing Inefficient Competitive Growth Paths: A Note on Capital Overaccumulation and Rapidly Diminishing Future Value of Consumption in a Fairly General Model of Capltalletic Production by David Cass.

557. The Demand for Intercity Passenger Transportation by Lester B. Lave.

558. Optimal Timing of Control Messages for a Two-State Markov Process by Nicholas J. Gonedes.

559. Enumerative Inequalities In Integer Programming by Claude-Alain Burdet.

560. Ranking the Facets of the Octahedron by Egon Balas.

561. Permutation Polyhedra by V. J. Bowman.

562. Canonical Cuts on the Unit Hypercube by Egon Balas and Robert Jeroslow.

563. Approximations to Interest Formulas by Yujl ljiri.

564. Theory of the Firm: Paet, Present, and Future; An Interpretation by Richard M. Cyert and Charles L. Hedrick.

565. A Note on Price Systems in Infinite Dimensional Space by Robert E. Lucas and Edward C. Prescott.

566. Predicting Behavlor from Attitudes by Alan G. Weinstein.

567. The Balance of Payments Composition Problem by Norman C. Miller.

568. Alr Pollution, Climate and Home Heating: Their Effects on U.S. Mortality Rate by Lester B. Lave and Eugene P. Seskin.

569. The Efficacy of a Comprehensive Health Care Project: An Empirical Analysis by Robert S. Kaplan, Leeter B. Lave, and Samuel Leinhardt.

570. Friedman's Monetary Theory by Karl Brunner and Allan H. Meltzer.

671. Money, Debt and Economic Activity by Kart Brunner and Allan H. Meltzer.

572. Integer Programming and Convex Analysis: Intersection Cuts from Outer Polars by Egon Balas.

573. Making Black Retall Outlets Work by Dennis Gensch and Richard Staelin.

574. MIS Technology-A Vlew of the Future by Charles H. Kriebel.

575. Comparison of $k$-Class Estimators when Disturbances are Small by Joseph B. Kadane.

576. Interest Rates on Monetary Assets and Commodity Price Index Changes by Richard Roll.

577. Risk Aversion and Wealth Effects on Portfolios with Many Assets by Davld Cass.

578. Intereat Rates and Price Expectations During the Civil War by Richard Roll.

579. Deep Cuts In Integer Programming by V. J. Bowman and G. L. Nemhauser.

580. Accelerated Algorithms for Labeling and Relabelling of Trees, with Applications to Distribution Problems by G. L. Thompson and V. Srinivasan.

581. The Appeal of Buying Black by Dennis Gensch.

582. On the Wicksellian Polnt-Input, Point-Output Model of Capital Accumulation: A Modern Vlew by David Cass.

583. Majority Rule Under Transitivity Constralnts by V. J. Bowman and C. S. Colantoni.

584. What the Commiseion Didn't Recommend by Allan H. Meltzer.

585. Measurement of a Composite Criterion of Managerial Success by Allan Shocker, V. Srinivasan, and Allan Weinstein.

586. Hospltal Cost Estimation Controlling for Case-Mix by Judith Lave, Lester Lave and Lester Silverman.

587. The Evaluation of Management Information Systems by Charles H. Kriebel.

588. Measuring and Teating Advertising Effectiveness with Split-Cable TV Panel Data by Timothy W. McGuire.

589. The Dellvery of Ambulatory Care to the Poor by Judith Lave and Samuel Leinhardt.

596. An Operator Theory of Parametric Programming for the Transportation Problem by $G$. $L$. Thompson and V. Srinivasan.

598. Mathematical Control Theory Solution of an Interactive Accounting Flow Model by Yujl IfIII and Gerald L. Thompson.

Management Information Systems: Progress and Perspectives (Carnegie Press, 1971). Editors: C. H. Kriebel, R. L. Van Horn, and J. T. Heames. Price: $\$ 10.50$. 